\title{
New taxa and combinations in Neotropical Delphacini (Hemiptera: Fulgoroidea)
}

\author{
ANA M. MARINO DE REMES LENICOV ${ }^{1} \&$ M. EUGENIA BRENTASSI ${ }^{2}$ \\ ${ }^{1}$ División Entomología, Anexo Laboratorios de Museo. Facultad de Ciencias Naturales y Museo, Universidad Nacional de La Plata. \\ Av. 122 y 60. La Plata, Buenos Aires, 1900,Argentina.CONICET.E-mail: amarino@fcnym.unlp.edu.ar, marinoremes@gmail.com \\ ${ }^{2}$ División Entomología, Anexo Laboratorios de Museo. Facultad de Ciencias Naturales y Museo, Universidad Nacional de La Plata. \\ Av. 122 y 60. La Plata, Buenos Aires, 1900,Argentina. CIC. E-mail: eubrenta@fcnym.unlp.edu.ar \\ ${ }^{1}$ Corresponding author. E-mail: marinoremes@gmail.com
}

\begin{abstract}
A new South American genus of Delphacini (Hemiptera: Fulgoromorpha: Delphacidae), Neodelphax n. gen., is described. It includes a new species, N. sakakibarai sp. n., which is described herein, and two species that are removed from the genus Dicranotropis. All of them are illustrated. Supplementary descriptions of female N. fuscoterminata (Berg) comb. n. and $N$. acheron (Fennah) comb. n., including some new records and host plant associations are added. A preliminary key for males and females of South American species of Neodelphax with representative illustrations is also provided.
\end{abstract}

Key words: Auchenorrhyncha, planthopper, new genus, new species Neodelphax fuscoterminata (Berg) comb. n., $N$. acheron (Fennah) comb. n., Argentina, Chile

\section{Introduction}

The planthopper tribe Delphacini is a diverse group with 29 genera recorded from the Neotropical Region (counts updated from Asche, 1985), including many of economic significance. To date, the known diversity of Delphacini in Argentina is 32 species in 16 genera (Remes Lenicov \& Cabrera Walsh 2013, Remes Lenicov \& Varela 2014). An ongoing study of the features of Neotropical Dicranotropis Fieber suggests that the species represented in Argentinean and Chilean agroecosystems: D. fuscoterminata (Berg) and D. acheron Fennah, respectively, differ considerably from those widely distributed in the Palearctic region, mainly in carination and genital structures.

The genus Dicranotropis, established by Fieber (1866) for the type species Delphax hamata Boheman, has, as recognized diagnostic features, the following characteristics: conspicuous submedian carina forked below apex of head, from one-fourth to one-half low on the face, with branches usually well separated; vertex almost square anteriorly, evenly rounded towards the frons in profile; and carination of pronotum with the lateral carina strongly curved, not reaching the hind border. Kirkaldy (1907) established the genus Leimonodite for Dicranotropis beckeri Fieber, highlighting that the carination of the head have the submedian carina of the frons separated near the frontoclypeal suture, but currently this taxon is considered a subgenus of Dicranotropis (Guglielmino et al. 2016). Crawford (1914) revised the New World delphacid fauna and included Pissonotus Van Duzee and Peregrinus Kirkaldy as synonyms of Dicranotropis [deemed an error by Metcalf (1943: 230)]. Bartlett (2014) compiled information about Dicranotropis and recognized two subgenera and 27 species worldwide, remarking that the four species recorded for the New World were probably incorrectly placed. Recently, Guglielmino et al. (2016) revised the Dicranotropis hamata group with interesting biogeographic and phylogenetic considerations. They highlighted, as diagnostic features for males, the shape of protuberances of the pygofer, the number of aedeagal spines and the spinose processes on the inner margin of the parameres.

As a result of the combination of the exclusive genitalic features shared by South American species, a new genus, Neodelphax n. gen., is proposed to include a new species, $N$. sakakibarai sp. n., described herein, and two species transferred from Dicranotropis. This study also gives information about host plants, geographical distribution and potential sanitary importance of these species. A preliminary key for males and females from 
South American species of Neodelphax is provided, including diagnostic characteristics of the genital segments of females, which are described for first time.

\section{Materials and methods}

All specimens (adults and nymphs) were captured in the field and preserved in $70 \% \mathrm{EtOH}$ for morphological studies. Additional individuals were frozen dry at $-18^{\circ} \mathrm{C}$, in order to preserve the original colors. The macropterous male was described in detail, but for females and the other winged forms only differential traits were specified. Morphological terminology follows Asche (1985), but segment X and anal style (segment XI) are used instead of anal tube. For descriptive purposes, parameres will be referred to as having a proximal basal angle, and distal inner and outer angles after Bartlett (2007). Phallotheca is here used instead of aedeagus, considering the fusion of the true aedeagus with the theca. Other components associated with the phallotheca are described following the terminology established by Bourgoin (1987). Genital complex is used descriptively for the phallotheca, connective, parameres, and postgenital segments when these structures are separate from the pygofer. Nomenclature of carinae of the vertex follows Yang \& Yang (1986). Both male and female genitalia of the species were prepared for microscopic examination according to standard techniques (Remes Lenicov \& Virla 1993). Measurements (median and range) were taken from 5 specimens of each gender and wing form, and are given in millimeters. Photographs of habitus and genital structures were taken using a RRID $18 \mathrm{HD}$ digital camera attached to a LEICA EZ5 stereoscopic microscope. Digital images were assembled using Combine ZM open software (Hadley 2011).

The following measurements are reported (abbreviations between parentheses): Total length (L.) in macropterous: from apex of vertex to apex of wings, forewing in repose; in brachypterous: from apex of vertex to tip of abdomen. Body length (B.L.) in macropterous: from apex of vertex to tip of abdomen. Body width (W.): maximum width at external margin of tegulae. Head width (w.): maximum width at external margin of eyes. Length: width ratio of the vertex (L:W): measured at midline and midlength, respectively. Forewing length (w.l.): taken on specimen in repose. Number of teeth on metatibial spur (t.n.). Other measurements are relative.

Specimens were deposited in the collections of the Museo de La Plata (MLP), Argentina.

\section{Taxonomy}

\section{Neodelphax new genus}

Type species: Neodelphax sakakibarai Remes Lenicov \& Brentassi, sp. n.

Description. Body robust, black to stramineous with distinctive dark marks at apex of clavus, nodal line and apical angle of forewing in macropterous form; carinae of head and pronotum, legs, antennae, rostrum and anal style yellowish. Head, including compound eyes, slightly larger than pronotum, vertex subquadrate, weakly projecting between eyes in dorsal view. Carinae of head strong and conspicuous, submedian carinae forked approximately in middle of vertex, joined onto frons below midlength, far below lower level of eyes; branches parallel and approximated. Frons with lateral margins subparallel, slightly narrowed between eyes. Lateral carinae of pronotum curved, diverging, not reaching posterior margin; median carina reaching hind margin at shallow notch. Lateral carinae of mesonotum straight, reaching posterior margin, median carina becoming obsolete in scutellum. Forewings of brachypter male opaque, concolorous with body; in females clear or light brown; slightly rounded, leaving exposed three tergites. Apex of hind tibiae bearing $5(3+2)$ spines, $7(5+2)$ on basitarsus and 4 on second tarsomere. Calcar with $22-28$ teeth.

Males darker than females, with abdomen and lateral portion of mesonotum more strongly embrowned.

Male terminalia: Genital segment ventrally longer than dorsally (about 3:1), pygofer with anal foramen rhomboidal, in dorsal view strongly excavate on both margins; in lateral view, dorso-caudal margin regularly curved, continuing downwards with scabrous, carinated and lightly projected margin; in caudal view, ventral margin deeply excavated with small, denticulate median process (often very little notorious). Diaphragm bridge subrectangular, armature much broader than its height, weakly to strongly sclerotized, middle of dorsal margin 
slightly lipped in lateral view. Parameres dorsolaterally directed in lateral view, diverging in caudal view; abruptly and strongly produced laterad near apex and slightly recurved at tip; basal angle developed in a medioventrallydirected edge; inner lateral margin smooth. Phallotheca tubular, terete to subterete, laterally slightly compressed, dorsally directed, armed with spinose process originated from lateral side, with small denticles on both margins near the apex, phallotrema apical, open on left side; suspensorium short, plate-like. Anal segment broad, ventrally membranous, bearing strongly developed lateral lobes ending in a strong spinose process. Anal style relatively small, slightly taller than wide.

Female genitalia: Abdomen with a wide, central, membranous part between pregenital sclerites. Genital scale strongly developed, triangular to subrectangular, with spinose process on caudal margin. Valvifers VIII elongate, broadening towards the base, with distinctive basal lobe on the inner margin. Gonapophyses IX slender and slightly curved, dorsally finely denticulated, with 20-40 small sharp teeth on distal 1/2.

Etymology. The generic name is a combination of the Greek véoৎ (néos), meaning new, plus delphax, a common termination used in delphacids. The name is to be treated as masculine [(Delphax was affirmed as masculine by ICZN (1961)].

Remarks. Neodelphax species can be easily recognized by the distinctive frontal carination, with the submedian frontal carina forked below the eyes (an uncommon feature in Delphacini); by the regularly convex dorsocaudal margin of the pygofer and the spinous caudal processes on the anal segment well developed. It also has the phallotheca semitubular and dorsally directed bearing a spinose process from the lateral side and small apical or subapical teeth. The female can be distinguished by the well developed genital scale, which is, caudally armed with spinous processes combined with the basally wide valvifers VIII. Neodelphax species share some external features with the recognized Palearctic species of Dicranotropis s.s. but can be separated from the latter by the lack of its distinctive genitalic features provided by the shape of the pygofer which is projected caudally on the dorsocaudal margin and with a spined process in medioventral position; the phallotheca compressed and ventrally bent; parameres sub-basally with scabrous surface and acute spine-shaped process (with smooth edge in Neodelphax) and the anal segment with small tooth in sub-basal position in male; the caudal margin emarginated of the genital scale in female is also absent. Two species from Neotropic placed in Dicranotropis: D. bipectinata Muir, from Ecuador and D. basifuscata (Fowler) from Mexico, have been examined only based on the original descriptions and some few illustrations. They show quite remarkable anatomical differences, particularly in the shape of pygofer, that is elongate and caudally projected, and the position of the phallotheca, ventrally directed, what actually justifies their exclusion from Neodelphax.

The three species presently included in this genus are $N$. sakakibarai $\mathbf{s p .}$ n., N. fuscoterminata (Berg) comb. n. and $N$. acheron (Fennah), comb. $\mathbf{n}$.

Distribution. Argentina and Chile.

\section{Key to males and females of Neodelphax species.}

The three species of Neodelphax recognized from our studies can be distinguished by the following key.

1. General coloration predominantly dark brown to black, except carinae, antennae and legs yellowish (Figs 14a, 15a). Vertex subquadrate, basal compartment relatively short (Figs 14b, 15b). Submedian frontal carinae joined far below lower level of

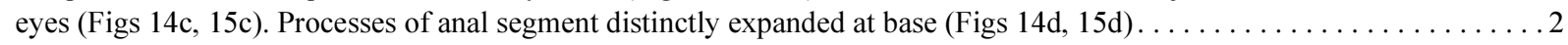

- General coloration yellowish brown with lighter intercarinal areas of frons, antennae and legs (Figs 16a, c). Vertex shorter than wide, basal compartment relatively large (Fig. 16b). Submedian frontal carinae joined just below lower level of eyes (Fig.

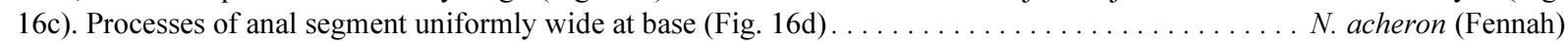

2. Male with pygofer distinctly marked with yellow on dorso-lateral margin. Processes of anal segment slightly dilated subapically and projected in acute apical spine; parameres S-shaped with inner angle obscure; phallotheca short and laterally depressed with caudal process slender, ventrally projected closely below phallotrema (Fig. 14d). Female with genital scale subtriangular, strongly produced caudally (Fig. 14e), valvifer VIII expanded basally (Fig. 14f). Spur with $26-28$ acute fine teeth .

. N. fuscoterminata (Berg)

Male pygofer uniformly brown dark, Processes of anal segment strongly wide basally, laterocaudad margins produced in welldeveloped claw-like process caudoventrad curved; parameres slender and sinuous, moderately curved apically, inner angle distinct; phallotheca tubular with a spinous flag-like process at $1 / 3$ apical (Fig. 15d). Females with genital scale wide and bispinose (Fig. 11), valvifer VIII widely produced at base (Fig. 12). Spur with $22-23$ acute teeth . . . . . . . N. sakakibarai sp. n. 


\section{Neodelphax sakakibarai Remes Lenicov \& Brentassi, sp. $\mathbf{n}$.}

(Figs 1-13)

Type locality: Villa Carmela, Departamento Tafí, Tucumán, Argentina, 2646'55"S, 6515'33"W.

Description. Male medium-sized, with macropterous and brachypterous forms (Figs 1, 2). Length of macropterous form: $3.9 \mathrm{~mm}$ in male, $4.2 \mathrm{~mm}$ in female; brachypterous form: $2.7 \mathrm{~mm}$ in male, $3 \mathrm{~mm}$ in female.

Darkish, ferruginous. Face with carinae testaceous pale, areas between carinae dark brown, irregularly pale dotted, except for clypeus which is uniformly colored; rostrum yellowish with darkish tip; ocelli and antennae yellowish with distinctive blackish antennal flagellum; vertex and pronotum with carinae testaceous pale; mesonotum uniformly brown except for small, testaceous apical mark; legs yellowish except coxae; upper side of abdomen uniformly dark; pygofer dark brown with small pale-colored area on each dorsolateral margin; anal style pale in dorsal view; anal spines dark brown; forewings (brachypterous) coriaceous, ferruginous, with apical half of suture black and adjacent area of wing darkish, in macropterous specimens, translucent brown forewings, with dark veins, except for longitudinal sub-hyaline subcostal+radial apical area; with elongate dark marking at tip of clavus and wide ferruginous semicircular-shaped area from cross-veins to apical margin up to M1 vein. Females: similar to males but generally lighter; areas between frontal carinae light brown, narrowly bordered with black.

Structure. Macropterous male.

Head (Figs 1,3 ) including compound eyes $2.7 \mathrm{x}$ wider than vertex at base, and slightly narrower than pronotum (0.9:1); vertex subquadrate, lateral margins subparallel, in midline approximately as long as wide at base; basal compartment at hind margin $3 \mathrm{x}$ as wide as greatest length, about $0.5 \mathrm{x}$ length of vertex; stem of Y-shaped carina slender, delimiting triangular shallow depressed areas on both sides; other carinae of head prominent. Vertex evenly rounded to frons in profile, fastigium slightly projecting beyond eyes; arms of submedian carina meeting at acuminate angle far below lower level of eyes. Frons (Fig. 4) longer than wide (2:1) in middle line, widest part at level of ventral margin of eyes, lateral margins slightly convex; submedian carinae prominent, straight, separate for $>3 / 4$ total length, branches closer to each other than to laterals, shallowly concave laterally; frontal area nearly straight in profile. Genal carina arising from lateral edge of frontoclypeal suture and ending before base of antenna. Postclypeal disc longer than width at base (1.4:1); median and lateral carinae prominent, submedian carinae continuing onto anteclypeus. Post and anteclypeus together little shorter than frons (0.9:1). Rostrum reaching middle of metacoxa, subapical segment slightly longer than apical segment (1:0.8). Antennal segments cylindrical, slender, surpassing base of postclypeus; basal segment as long as width, second segment longer than first segment (2:1); number and arrangement of sensory fields of pedicel: 14 in 5 rows.

Pronotum (Fig. 3) wider than head (1.1:1), in midline slightly shorter than vertex; lateral carinae distinct, curved laterally behind eye, not reaching hind margin. Mesonotum $3 x$ length of pronotum medially in macropterous and $2 \mathrm{x}$ in brachypterous form; carinae distinct, straight, lateral carinae ending on margin, median carina becoming obsolete prior to scutellum, which is as smooth as scutum. Forewings (Fig. 1) rounded at apex, length $3 \mathrm{x}$ its width at apical region, in brachypterous form reaching genital segment and hind wing reduced to scale. Post-tibial spur (Fig. 5) oval, concave on inner surface, slightly shorter than basitarsus (0.7:1) with about 22 23 slender black-tipped teeth on posterior margin plus inconspicuous apical tooth. Postbasitarsus slightly longer than tarsomere II and III together (1:0.8); spinal formula: 5 (grouped $2+3$ ) -7 (grouped $2+5$ ) - 4. Drumming organ (Fig. 6) distinctive, with second abdominal tergite differentiated into distinctive plate readily visible externally surrounded by white membranous area; central plate subquadrate, medially convex, laterocaudally closed by sclerotized furrows.

Genitalia. Genital segment (Figs 7-9) ovate in caudal view, slightly wider than height; dorsal margin, deeply excavated to hold anal segment; trapezoidal in lateral view, ventral length $3 \mathrm{x}$ dorsal length; dorsocaudal margins smoothly rounded, ventrolaterally slightly projected, distinctively scabrous and sclerotized; ventrocaudal margin deeply excavate with small median process. Diaphragm bridge subrectangular, armature much broader than height, strongly sclerotized; middle of dorsal margin convex, slightly lipped in lateral view. Parameres rather long, slender, distally diverging and tapering, angled dorsal in apical third, apex recurved outwards; basal angle with well developed rounded edge directed medioventrad, inner lateral margin smooth. Phallotheca tubular, terete to subterete, laterally slightly compressed, obliquely dorsally directed and armed with relatively short spinous lateral flag-like process 1/3 distance from apex, with crown of 6-8 small teeth surrounding dorsal and lateral sides of apical phallotrema; phallotrema circular exposed on left side; suspensorium short, plate-like, widely attached to 
ventral base of phallotheca. Connective nearly straight, compressed. Anal segment broad, ventrally membranous, widely separated at base in caudal view, with laterocaudad margins projected in strong claw-like process medioventrad directed. Anal style relatively small, little higher than wide.

Measurements of macropterous: L.: 3.95 (3.91-4.08); B.L: 2.95 (2.66-3.08); W.:1.08 (1.06-1.16); w.: 0.78 (0.75-0.8); w.1.: 3.07 (3.05-3.15); t.n.: 22-24.

Measurements of brachypterous: L.: 2.70 (2.50-2.83); W.: 0.97 (0.91-1); w.: 0.75; w.l.: 1.61 (1.55-1.65); t.n.: $22-23$.

Female. Macropterous form: Structure and color pattern similar to male but lighter; abdominal segments usually with darkish marks on each side of tergites and sternites. Drumming organ inconspicuous, without major morphological variations. Brachypterous form: structurally similar to brachypterous males, color pattern varying from darkish to uniformly castaneous, with intercarinal frontal region, gena and forewings, brownish.

Genitalia (Figs 10-13): Abdomen with wide central membranous part between pregenital sclerites. Genital scale (Fig. 11) approximately rectangular, regularly sclerotized, with two strong submedian spinose processes as long as half scale length. Valvifers VIII (Fig. 12) elongate, strongly broadening towards base, with distinctive basal lobe on inner margin. Gonapophyses IX (Fig. 13) slender, dorsally finely denticulated, slightly curved in basal 1/2, with ca. 38-40 small sharp teeth on distal $1 / 2$ of dorsal margin, with distal apex narrow and strongly angled; anal style moderately short.

Measurements of macropterous: L.: 4.06 (3.83-4.33); B.L.: 3.11 (2.66-3.50); W.:1.13 (1.08-1.16); w.: 0.8 (0.75-0.85); w.1.: 3.03 (2.95-3.25); t.n.: 22-24.

Measurements of brachypterous: L.: 3.28 (3.16-3.5); W.: 1; w.: 0.8; w.1.: 1.6; t.n.: $22-23$.

Etymology. This species is named in honor of Dr. Albino M. Sakakibara, from the Universidad Federal do Paraná, Brazil, in recognition of his intense and prolific work as a taxonomist of auchenorrhynchous Hemiptera.

Remarks. Neodelphax sakakibarai can be easily recognized from the apparently closely related and widely distributed species $N$. fuscoterminata by the following characters: coloration pattern of body quite uniformly darker, forewings in macropterous form with fuscous marks and hyaline areas more extended and intensely colored; submedian frontal carina joined near apical margin, with the branches parallel and closely approximated; male genitalia with diaphragm bridge subrectangular with armature strongly sclerotized, parameres more slender and phallotheca with spinous lateral flag-like process at $1 / 3$ distance from apex. The four-sided shape and spinous processes of the genital scale and the expanded base of valvifers VIII are distinctive in the females.

Distribution. Argentina (Salta, Tucumán, Catamarca and Buenos Aires).

Biology: Neodelphax sakakibarai is common and abundant on meadows and cultivated fields in valleys of the Northwest of Argentina. The majority of the collection locations are in sub-Andean areas that belong to the Monte biogeographic province, that is characterized by a warm, shrubby desert extending to the east of the Andes

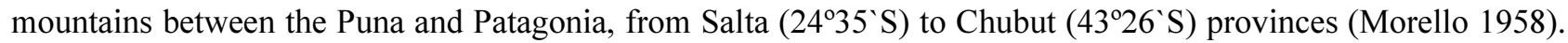
Field studies have shown that its populations abruptly increase during late winter and early spring living on several wild grasses surrounding cultivated maize areas affected by the Mal de Río Cuarto virus (MRCV) (Remes Lenicov unpubl. data). Further studies will determine its role in the epidemiology of this disease.

Several species of plants have been registered predominantly in corn agroecosystem of subtropical areas in the north of Argentina where N. sakakibarai was captured: Sorghum halepense L., Cynodon dactylum (L.) and Setaria sp. (Poaceae) and the dicots Eryngium sp. L (Apiaceae), Solanum nigrum L. (Solanaceae) and Sida rhombifolia L. (Malvaceae) (E. Virla, Pers. com., April 2017).

Natural Enemies. Nymphs and adults were found parasitized by unidentified species of Elenchidae (Strepsiptera) and Dryinidae (Hymenoptera).

Material Examined. Holotype male (macropter): ARGENTINA, Tucumán, Villa Carmela, on grass, 28.VIII.1998, Virla col. Paratypes: 3 males (brachypters), 3 females (macropters), 2 females (brachypters), same data as holotype; 1 male and 1 female (macropters), Tucumán, Las Tipas, Trancas, 28.I.1999, Virla col.; 1 male (macropter), Salta, Rosario de Lerma, 17.V.1994; 1 male (macropter), Catamarca, El Rodeo, 27.II.1999, Virla, col.; 1 male (macropter), 1 female (brachypter), Buenos Aires, Balcarce, on maize, XII.1991, Remes Lenicov col. (MLP); 1 male (macropter), 1 female (brachypter), Buenos Aires, La Plata, on grass, 10.V.1999, Barrios col.

Other Material Examined. ARGENTINA: Tucumán, 5 males (macropters), 3 males (brachypters), 3 females (macropters), 2 females (brachypters), Villa Carmela, on Cynodon sp. 


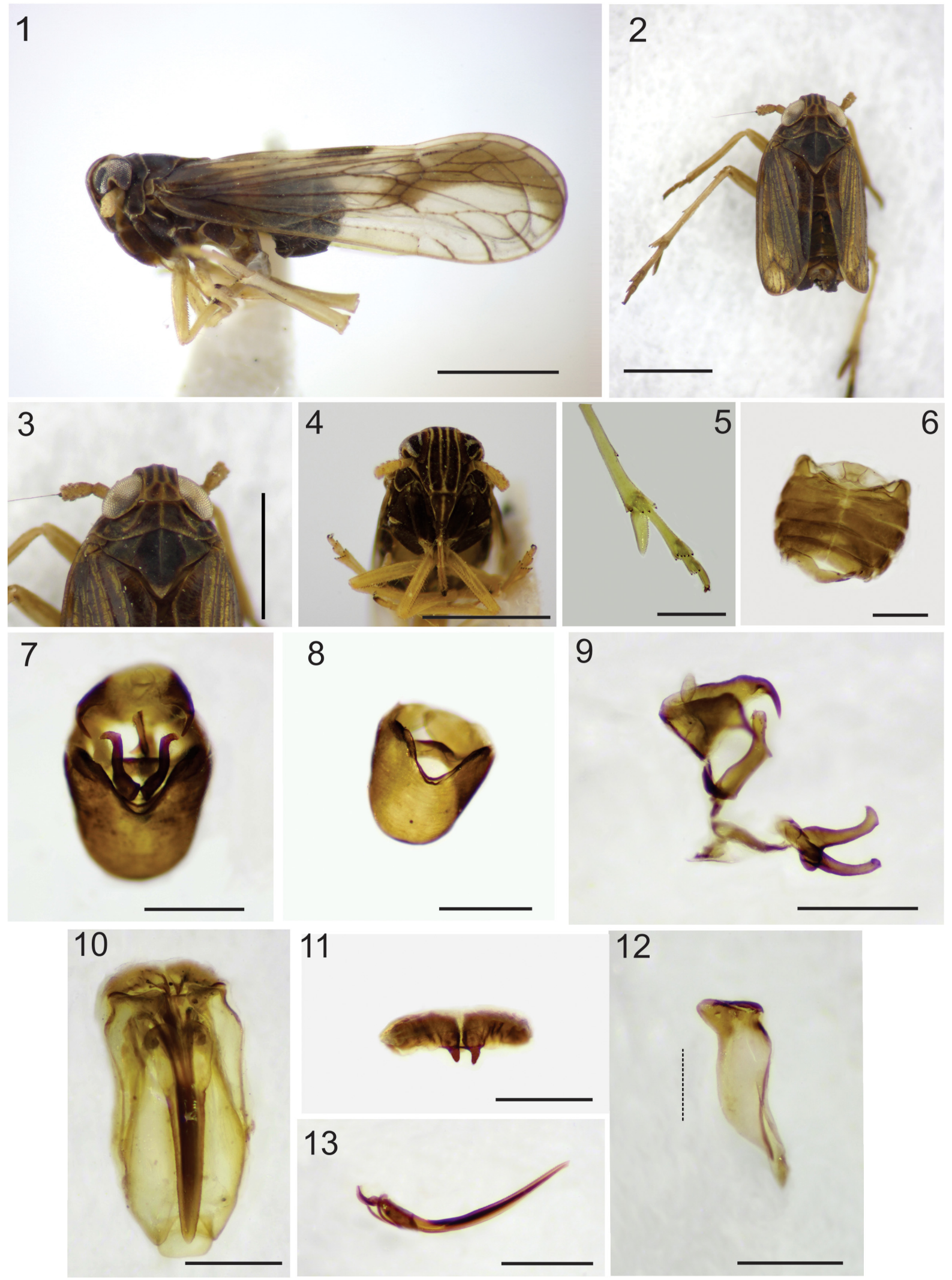

FIGURES 1-13. Neodelphax sakakibarai sp. n. 1, male holotype, habitus, lateral view; 2, brachypter male, habitus, dorsal view; 3, head and thorax, dorsal view; 4, head, frontal view; 5, apex of hind leg (post tibial spur and tarsi); 6, pregenital segments of abdomen, dorsal view; 7, male genitalia, caudal view; 8, pygofer, ventro caudal view; 9, genital complex, left lateral view. Female: 10, genitalia, ventral view; 11, genital scale, ventral view; 12, right valvifer VIII; 13, median gonapophysis IX, lateral view. Scale lines: Figs $1-4=1 \mathrm{~mm}$; Figs $5-13=0.5 \mathrm{~mm}$. 
Neodelphax fuscoterminata (Berg) comb. $n$.

(Figs $14 \mathrm{a}-\mathrm{g}$ )

1879. Liburnia fuscoterminata Berg: 296.

1879. Liburnia nigricula Berg: 296; syn. by Remes Lenicov, 1996: 124.

1914. Megamelus fuscoterminata (Berg); comb. by Crawford: 632 .

1914. Megamelus nigricula (Berg); comb. by Crawford: 632 .

1926. Delphacodes fuscoterminata (Berg); comb. by Muir: 38.

1926. Delphacodes nigricula (Berg); comb. by Muir: 37.

1996. Dicranotropis fuscoterminata (Berg); comb. by Remes Lenicov, 1996: 124.

Emended diagnosis. General coloration predominantly dark brown to black, except carinae, antennae and legs yellowish. In macropterous form, forewings hyaline, with brown elongated spots on the area between the crossveins and the apical margin. Vertex subquadrate, basal compartment relatively short. Submedian frontal carinae joined far below lower level of eyes. Processes of anal segment large, distinctly dilated subapically and projected in acute apical spine; parameres S-shaped, regularly curved apically, inner angle obscure; phallotheca short; caudal process slender, ventrally projected closely below phallotrema; phallotrema oval on left side.

Supplementary description. Female genitalia: Abdomen with membranous central part between pregenital sclerites. Genital scale (Fig.14e) heart-like, ending in strong spinose median process as long as scale length. Valvifers VIII (Fig. 14f) elongate, slightly broadening towards base, with rounded basal lobe on inner margin. Gonapophyses IX (Fig. 14g) slender, dorsally finely denticulated, slightly curved in basal 1/2, with ca. 20-22 small sharp teeth on dorsal margin in distal $1 / 2$, with distal apex narrow and strongly angled; anal style moderately short.

Supplementary Measurements.

Male: Macropterous: L.: 3.83 (3.33-4); B.L.: 2.5 (2.41-2.66); W.:1.05 (1-1.08); w.: 72 (0.70-0.74); w.1.: 2.85 (2.8-2.9); t.n.: 26-28. Brachypterous: L.: 2.2 (2-2.4); W.: 0-91; w.:0.65; w.1.: 1.22; t.n.: 24-28.

Female: Macropterous: L.: 4.08 (3.91-4.16); B.L.: 3.08 (3-3.16); W.:1.13 (1.08-1.16); w.: 0.75; w.1.: 3.23; t.n.: 26-28. Brachypterous: L.:2.79 (2.75-3); W.: 1.04 (1-1.08); w.: 0.75; w.1.: 1.43 (1.3-1.5); t.n.: 26.

Remarks. Berg (1879) described Liburnia fuscoterminata based on a single macropterous male specimen from Chacabuco, Buenos Aires province, and L. nigricula based on a brachypterous male from Corrientes province in Argentina. Remes Lenicov (1996), based on the examination of type specimens, regarded L. nigricula as synonymous with L. fuscoterminata and transferred this species to Dicranotropis based mainly on the general aspect and carination of the head and pronotum. In that contribution, the author redescribed the male of $D$. fuscoterminata and added some traits for the female and other winged forms, new geographical records and host plants.

The most definitive feature that distinguishes $N$. fuscoterminata is the phallotheca, with a relatively short shaft and slender caudal terminal process arising close to the phallotrema in males, and the distinctive heart-shaped genital scale strongly produced in a stout caudal process in females (Figs 14d, e).

Distribution. ARGENTINA: Salta, Tucumán, Corrientes, Entre Ríos, Santa Fe, Córdoba, Mendoza and Buenos Aires, Remes Lenicov \& Virla (1999).

Biology. $N$. fuscoterminata is one of the most widely distributed delphacids in Argentina, being predominant within the humid Pampean region of central-western Argentina between $30^{\circ}$ and $39^{\circ} \mathrm{S}$, Morrone (2014). Contributions on morphological and bioecological aspects of this species, such as development stages and some demographic parameters were published by Remes Lenicov \& Virla (1999) and Remes Lenicov et al. (1997, 2008).

Sanitary importance. This species coexists with the main vector species, Delphacodes kuscheli Fennah, on maize agrosystems, within the endemic MRCV area (Remes Lenicov \& Virla 1999). Because of the high abundance of this species in crop areas infected with MRCV in central areas of Argentina, it is suspected as a vector of the pathogen.

Natural Enemies. Nymphs and adults were found parasitized by Pseudogonatopus chilensis Olmi (Hymenoptera, Dryinidae), Virla (1995), Cephalops penepauculus Hardy (Diptera, Pipunculidae), Virla \& Rafael (1996), Remes Lenicov \& Virla (1999) and one unidentified species of Elenchidae (Strepsiptera).

Material examined: Tucumán: 2 males (macropters), 2 males (brachypters), 1 female (macropter), 2 females (brachypters), S.M. de Tucumán, on maize, 12.02.1998, Virla col.; 2 males (macropters), 2 males (brachypters), 1 female (macropter), 2 females (brachypters), Tafí del Valle, La Quebradita, on Cynodon sp., 20.V.1998 Virla leg. 
Buenos Aires: 2 males (macropters), 2 males (brachypters), 2 females (macropters), 2 female (brachypters), Balcarce, on maize, XII.1991, Remes Lenicov col.; 3 males (macropters), 2 males (brachypters), 2 females (macropters), 2 females (brachypters), La Plata, on grass, XII.2006, Remes Lenicov col.; 1 male (macropter), 1 female (brachypter), Lomas de Zamora, on grass, 10.V.1999, Barrios col. (MLP).

\section{Neodelphax acheron (Fennah), comb. $\mathbf{n}$.}

(Figs $16 \mathrm{a}-\mathrm{g}$ )

1957. Dicranotropis acheron Fennah: 381.

1996. Dicranotropis acheron: Remes Lenicov: 126.

Emended diagnosis. General coloration yellowish brown with lighter intercarinal areas of frons, antennae and legs. In macropterous form, forewings hyaline, with light brown elongated spots on the area between the crossveins and the apical margin. Vertex shorter than wide, basal compartment relatively large. Submedian frontal carinae joined just below lower level of eyes. Processes of anal segment uniformly wide at base; parameres slender, strongly produced laterad near apex, with acute inner apical angle; phallotheca long, with fine denticles laterally aligned along apical half and spiniform process close to base projecting upwards.

Supplementary description. Female genitalia: Genital scale (Fig. 16e) nearly triangular, wide and rounded on anterior margin with relatively short, slender caudal process medially produced. Valvifers VIII (Fig. 16f) elongate, slightly broadening towards base, with rounded and relatively short basal lobe on inner margin. Gonapophyses IX (Fig. 16g) slender, dorsally finely denticulated, curved in basal $1 / 2$, with ca. 20-22 small sharp teeth on dorsal margin in distal $1 / 2$, with distal apex narrow and strongly angled; anal style moderately short.

Supplementary measurenment.

Male: Macropterous: L.: 3.45 (3.33-3.48); B.L: 2.25 (2.10-2.33); W.:0.92; w.: 0.67; w.1.: 2.9; t.n.: 20-22. Brachypterous: L.: 2.25; W.: 0.97 (0.91-1); w.: 0.8; w.1.: 1.2; t.n.: 20.

Female: Macropterous: L.: 3.62 (3.33-3.91); B.L: 2.91 (2.83-3); W.:1.02; w.: 0.75; w.1.: 2.57 (2.4-2.75); t.n.: 20-22. Brachypterous: L.:2.4; W.: 1.08; w.: 0.75; w.1.: 1.25; t.n.: 20-21.

Remarks. The general morphology and body and forewing coloration was well documented by Fennah (1957) based on a brachypterous male specimen. The macropterous male and female winged forms were described by Remes Lenicov (1996).

The most definitive featured that distinguish $N$. acheron from their congeners, are the smaller size, the yellowish brown coloration and the phallotheca with a relatively long shaft and slender short, spiniform process close to the base projected upwards, in males (Remes Lenicov 1996, fig.13, pg.126).

Distribution. Chile: Juan Fernández Islands, Masatierra; Bahía Cumberland (Fennah 1957, Remes Lenicov 1996). Recently, it was recorded in Continental Chile: Los Vilos (Coquimbo Region), $31^{\circ} 55^{\prime} \mathrm{S}, 71^{\circ} 31^{\prime} \mathrm{W}$, Mantagua (Valparaíso Region), 32 $38^{\circ} 33^{\prime \prime S}$ and $71^{\circ} 50^{\prime} \mathrm{W}$ and Chaihuín (Los Ríos Region) 39 $9^{\circ} 93^{\prime} 33^{\prime \prime S}$ and $73^{\circ} 58^{\prime}$ 33"W, Campodonico (2015).

This species represents the southernmost limit of the genus.

Biology. Campodonico (2015) collected all the specimens of $N$. acheron in coastal places; in Montagua and Chaihuín they were found on grasslands next to bodies of water, while in Los Vilos collections they were collected in grasslands next to the forest swamp of Ñagué.

Natural Enemies. Adults were found parasitized by unidentified species of Dryinidae (Hymenoptera) as Olmi, in lit., Remes Lenicov (1996).

Material examined: CHILE: 3 males (macropters), 3 males (brachypters), 3 females (macropters), 3 females (brachypters), Juan Fernández; Robinson Crusoe I, Bahía Cumberland, 5.I.1992, Olmi leg., 2 males (macropters), 2 males (brachypters), 2 females (macropters), 2 females (brachypters), Puerto Francés, Robinson Crusoe.1, 9.I.1992, Olmi leg. (MLP). 

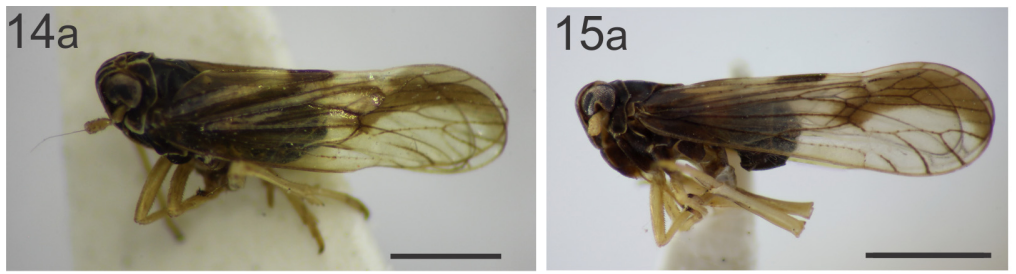

$16 a$
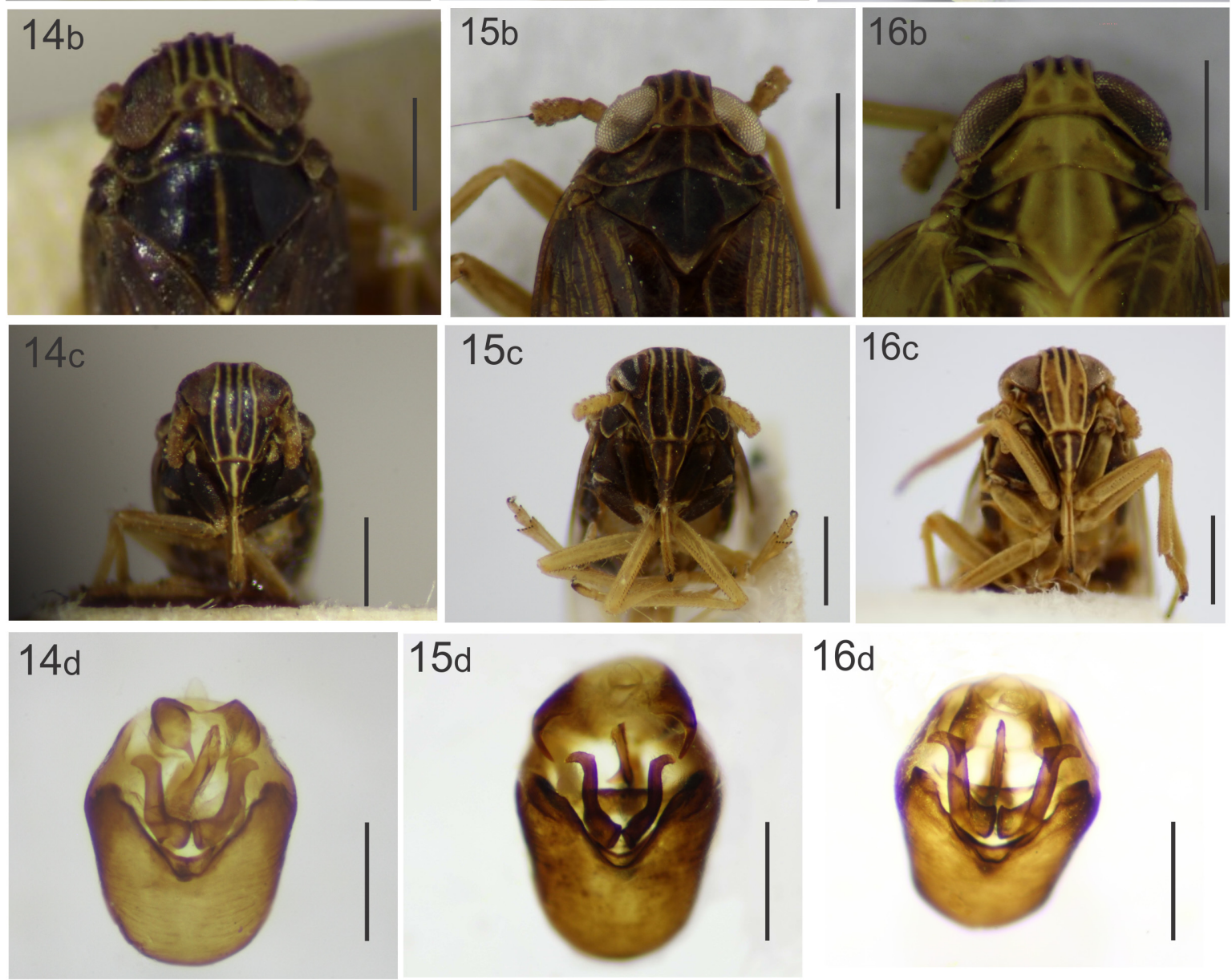

$15 d$

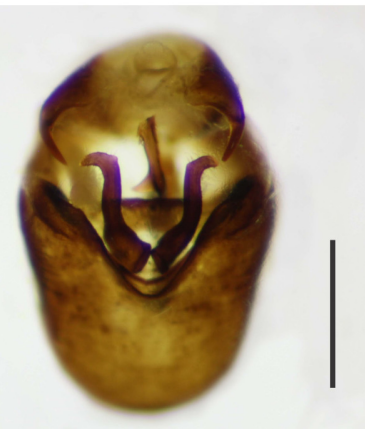

$16 d$
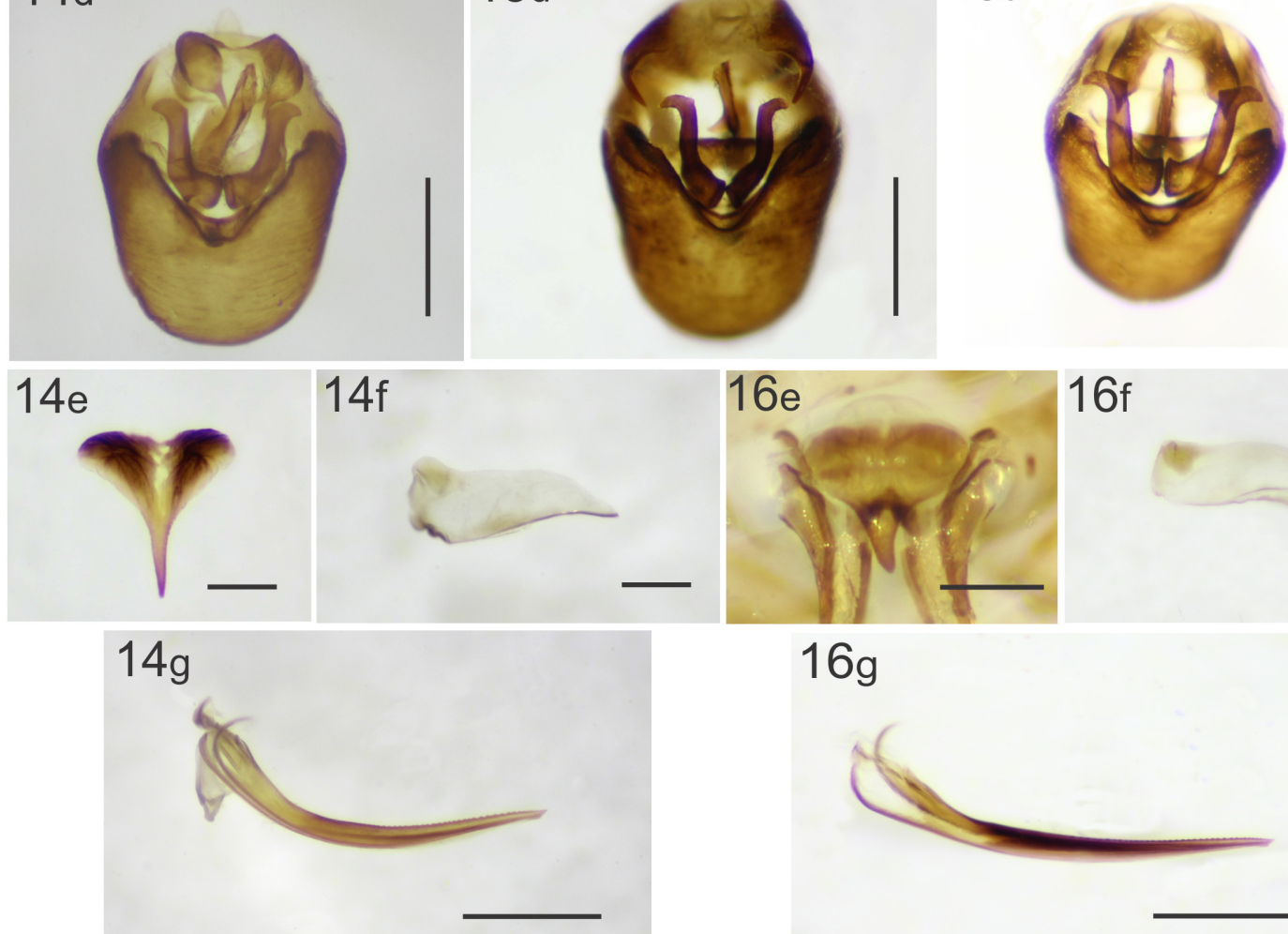

$16 f$

$16 \mathrm{~g}$

FIGURES 14-16. Comparative features that distinguish species of Neodelphax n. gen. 14 (a-g), N. fuscoterminata (Berg). a c, Habitus, male: a, lateral view, b, head and thorax, dorsal view, c, head, frontal view; d, male genitalia, caudal view; e-g, Female: e, genital scale, ventral view, f, right valvifer VIII, g, median gonapophysis IX, lateral view. 15, N. sakakibarai sp. n.; a -c, Habitus, male: a, lateral view, b, head and thorax, dorsal view, c, head, frontal view; d, male genitalia, caudal view.16, $N$. acheron (Fennah); a -c, Habitus, male: a, lateral view, b, head and thorax, dorsal view, c, head, frontal view; d, male genitalia, caudal view; e-g, Female, e, genital scale, ventral view, f, right valvifer VIII, g, median gonapophysis IX, lateral view. Scale lines: Figs. 14-16 (a) =1 mm; Figs. 14-16 (b, c, d, g) =0.5 mm; Figs. 14-16 (e, f) =0.25 mm. 


\section{Acknowledgements}

We especially thank Chris Dietrich and the Co-Editors, Daniela Takiya and Olivia Evangelista for the invitation to join to the Festschrift in honor of Prof. Albino Sakakibara. In particular, because the first of us (AMMRL) not only had the honor of sharing with him the co-authorship of one of her early contributions, but also his expertise and materials during the first steps of her career while working on her $\mathrm{PhD}$ thesis on membracid taxonomy. We also thank to Dr. Eduardo Virla (PROIMI-CONICET and IML, UNT, Tucumán) who provided us most of the specimens collected in northwest Argentinean areas and Dr. Arnaldo Maciá (CIC: Scientific Research Committee of the Province of Buenos Aires, Argentina) for the technical assistance. This work was partially supported by the National Research Council (CONICET), Scientific Research Committee of the Province of Buenos Aires (CIC) and La Plata National University (UNLP) from Argentina (Project Code 623 and 630).

\section{References}

Asche, M. (1985) Zur phylogenie der Delphacidae Leach, 1815 (Homoptera: Cicadina Fulgoromorpha). Marburger Entomologische Publikationen, 2 (1-2), 1-910.

Berg, C. (1879) Hemiptera Argentina. Enumeravit Speciesque Novas. Anales de la Sociedad Cientifica Argentina, 7-8, 9-316.

Bartlett, C.R. (2007) A review of the planthopper genus Nilaparvata (Hemiptera: Delphacidae) in the New World. Entomological News, 118, 49-66. https://doi.org/10.3157/0013-872X(2007)118[49:AROTPG]2.0.CO;2

Bartlett, C.R. (2014) (and updates). Delphacid planthoppers of North America. Newark, Delaware, USA: University of Delaware, College of Agriculture \& Natural Resources. Available from: http://ag.udel.edu/research/delphacid/species/ Dicranotropis.html (accessed 26 November 2016)

Bourgoin, T. (1987) A new interpretation of the homologies of the Hemiptera male genitalia, illustrated by the Tettigometridae (Hemiptera, Fulgoromorpha). 6th Auchenorrhyncha Meeting, 113-120, 1-652.

Crawford, D.L. (1914) A contribution toward a monograph of the homopterous insects of the family Delphacidae of North and South America. Proceedings of the United States National Museum, 46, 557-640. https://doi.org/10.5479/si.00963801.46-2041.557

Campodonico, J.F. (2015) Sobre la distribución de Dicranotropis acheron Fennah, 1957 (Hemiptera: Fulgoroidea: Delphacidae) en Chile. Arquivos Entomolóxicos, 14, 265-268.

Fennah, R.G. (1957) Los insectos de las Islas Juan Fernández 29. Fulgoroidea. Revista Chilena de Entomología, 5, 375-384.

Fieber, F.X. (1866) Grundzüge zur generischen Theilung der Delphacini.Verhandlungen der Kaiserlich-Königlichen Zoologisch-botanischen Gesellschaft in Wien, 16, 517-534.

Guglielmino, A., D’Urso, V. \& Bückle, Ch. (2016) Revision of the Dicranotropis hamata group (Auchenorrhyncha, Delphacidae) and remarks on the implication of chiral dimorphism in its history. Deutsche entomologische Zeitschrift, 63 (1), 89-108. https://doi.org/10.3897/dez.63.6625

Hadley, A. (2011) Combine ZP-Free image stacking software for depth of field correction. http://www.hadleyweb.pwp.blueyonder.co.uk/CZM/combinezm.htm (accessed 21 September 2011)

International Commission on Zoological Nomenclature (1961) International Code of Zoological Nomenclature. International Trust for Zoological Nomenclature, London, $176 \mathrm{pp}$.

Kirkaldy, G.W. (1907) Leafhoppers supplement (Hemiptera). Bulletin of the Experiment Station of the Hawaiian Sugar Planters' Association, Entomological Series 3, 1-186, 20 pls.

Metcalf, Z.P. (1943) General Catalogue of the Hemiptera. Fascicle IV, Fulgoroidea, Part 3. Araeopidae (Delphacidae). Smith College, Northhampton, Massachusetts, $552 \mathrm{pp}$.

Morello, J. (1958). La provincia Fitogeografica del Monte. Opera Lilloana, 2, 1-155.

Morrone, J.J. (2014) Biogeographical regionalization of the Neotropical region. Zootaxa, 3782 (1), 001-110.

Muir, F. (1926) Contributions to our knowledge of South American Fulgoroidea (Homoptera). Part I. The Family Delphacidae. Experiment Station of the Hawaiian Sugar Planters 'Association. Entomological Series Bulletin, 18, 1-51, pls. 1-5.

Remes Lenicov, A.M.M. de (1996) El género Dicranotropis Fieber, 1866, en la República Argentina y Chile (Insecta: Homoptera: Delphacidae). Acta Entomológica Chilena, 20, 123-128.

Remes Lenicov, A.M.M. de, Brentassi, M.E. \& Toledo, A. (2008) Description of the immature stages of Delphacodes kuscheli Fennah (Hemiptera: Delphacidae), vector of "Mal de Río Cuarto virus" on maize in Argentina. Studies on Neotropical fauna and Environment, 43 (1), 25-33. https://doi.org/10.1080/01650520701322701

Remes Lenicov, A.M.M. de \& Cabrera Walsh, G. (2013) A new genus and species of Delphacini associated to hydrophytic plants in Argentina (Hemiptera: Fulgoromorpha: Delphacidae). Florida Entomologist, 96 (4), 1350-1358. https://doi.org/10.1653/024.096.0414 
Remes Lenicov, A.M.M. de, Mariani, R. \& Costamagna, A. (1997) Aspectos morfológicos y bioecológicos de Dicranotropis fuscoterminata (Berg) sobre cultivos de maíz. (Insecta-Homoptera-Delphacidae). Neotrópica, 43 (109-110), 7-14.

Remes Lenicov, A.M.M. de \& Varela, G. (2014). A new genera and species of Delphacini from Argentina (Hemiptera: Fulgoroidea-Delphacidae). Zootaxa, 3861 (2), 177-184. https://doi.org/10.11646/zootaxa.3861.2.5

Remes Lenicov, A.M.M. de \& Virla, E. (1993) Homopteros Auquenorrincos asociados al cultivo de trigo en la República Argentina. I. Análisis preliminar de la importancia relativa de las especies. Studies on Neotropical Fauna and Environment, 28 (4), 211-222. https://doi.org/10.1080/01650529309360905

Remes Lenicov, A.M.M. de \& Virla, E. (1999) Delfácidos asociados a cultivos de maíz en la República Argentina. (Insecta: Homoptera: Delphacidae). Revista de la Facultad de Agronomía, 104 (1), 1-15.

Virla, E.G. (1995) Biología de Pseudogonatopus chilensis Olmi 1989 (Hym. Dryinidae). Acta Entomológica Chilena, 19, 123127.

Virla, E.G. \& Rafael, J. (1996) Datos bionómicos preliminares y descripción de la hembra de Cephalops penepauculus (Hardy) (Diptera- Pipunculidae) un parasitoide de Delphacidae (Auchenorrhyncha) en Argentina. CIRPON Revista de Investigaciones, 10 (1-4), 33-36. [1994-1996]

Yang, J.T. \& Yang, Ch. T. (1986) Delphacidae of Taiwan (I). Asiracinae and the Tribe Tropidocephalini (Homoptera: Fulgoroidea). Collected Papers on Homoptera of Taiwan, 1986, 1-78. 